\title{
Analysis of Factors Influencing the Effectiveness of Village Financial Information System in Semarang Regency
}

\author{
NIKMATUNIAYAH, CH BUDHI ADHIANI, LILIS MARDIANA A \\ ${ }^{123}$ Accounting, State Polytechnic of Semarang, Jl. Prof Sudharto SH Tembalang Semarang \\ email: ${ }^{1}$ nikmatuniayah@rocketmail.com; ${ }^{2}$ budhi_ac@yahoo.com; ${ }^{3}$ ilis_mardiana68@yahoo.co.id
}

\begin{abstract}
The purpose of this study is to analyze the factors influencing the effectiveness of village financial information system. This study conducted according to a model proposed by Gupta et al. (2007). The Primary data used is based on the questionnaire distributed to the village government organization in Semarang Regency. There are 100 copies of the questionnaire has been sent, and returned $100 \%$ because it was delivered directly by the researchers. The data were analyzed using multiple regression with SPSS 16 software. The result showed that top management, information system management and user of information systems did not statistically influence the effectiveness of village financial information system. Meanwhile, user satisfaction and organizational culture had positive influence on the effectiveness of village financial information system.
\end{abstract}

Keywords: information system management, user satisfaction, organizational culture

\section{Introduction}

Accounting information system plays an important role in public sector accountability, where accounting and public accountability systems are central to the management of local government organizations. Public sector accounting infrastructure that has been built in decentralized governance is Standar Akuntansi Pemerintahan (SAP) or the Government Accounting Standard established by Government Regulation No. 24 of 2005. Standar Akuntansi Keuangan Sektor Publik (SAKSP) or The Public Sector Financial Accounting Standards are developed in accordance with international standards, such as the adaptation of the International Federation of Accountant (IFAC). Basically, the principles of development of SAP are oriented towards IPSAS, but are adapted to the conditions in Indonesia, such as by observing the prevailing laws and regulations, existing financial practices, and the readiness of resources of SAP users (Bastian, Indra 2006).

Setyoko, I Paulus (2011) analyzed that the financial reporting system and mechanisms that have been well established by the district government could not be properly implemented by village government officials. This failure was due to the low administrative capacity of the village government apparatus, the absence of strict sanctions from the district government regarding the irregularities of financial administration as well as the rural community who was less concerned with the accountability issues of the regional financial administration.

Yusnita, Y. Nina (2010) examined the effect of applying accounting principles on the quality of public sector financial reports with public accountability and transparency. The results showed that there was a significant effect between the application of accounting principles and the quality of financial statement information. However, in terms of the interaction of the application of accounting principles and public accountability and the quality of financial statement information showed no significant effect.

Semarang Regency is regency in Central Java province with capital city of Ungaran. Semarang Regency has 981.95 $\mathrm{km} 2$ widths with total population of 978.253 people (in 2009). It consists of 19 districts, and further divided into 208 villages and 27 sub-districts. Areas with residential density or distribution of urban areas a re the city center (Ungaran Sub-district), a reas along Semarang-Bawen corridor, as well as areas directly adjacent to Semarang and Salatiga

Received: October 15, 2017, Revision: April 20, 2018, Accepted: June 09, 2018

Print ISSN: 0215-8175; Online ISSN: 2303-2499. DOI: http://dx.doi.org/10.29313/mimbar.v34i1..213-223

Accredited B based on the decree No.040/P/2014, valid on February, 18, 2014 until February, 18, 2019. Indexed by DOAJ, Sinta, IPI 
Cities. People in Semarang Regency generally work in agriculture since the potential of Semarang Regency is its largely agricultural land. The rural area of Semarang Regency is compatible with Village Law No. 6 Year 2014, which states that the village is a region with population or people is primary livelihood are in agriculture, farming or agrarian (Yuliansyah \& Rusmianto 2015).

So far, the development of villages in Indonesia is not based on comprehensive analysis of human source who live in rural areas. Programs implemented are generally partial, sometimes there is no clear linkages between one program with another and even overlapping, so that the development is not effective and may result in wasting funds that have been allocated by the government (Zulfida I et al 2015).

The development of local financial management in order to optimize local government budget requires incorporation with the community, starting from planning to activities implementation, evaluation stages and emphasis on the effectiveness of internal and external supervisions (Maggasingang, Djainuddin 2015). Accounting information system is needed to improve the quality of local government financial reports and the performance of good governance as well. Village financial apparatus in Semarang Regency is now applying financial input by using village financial information system (SISKUEDES) from BPKP (Indonesian's National Government Internal Auditor). SISKUEDES is an application to manage receipt and expenditure of village funds. The system is implemented for all villages in Semarang Regency. However, the apparatus still experience a number of obstacles in its implementation, such as the village treasurer do not fully understand the village financial system, and there is inconsistency found in the application function if it uses from one laptop to another.

The village financial system becomes the primary need to be fulfilled by the local government especially because there are village funds that must be accounted for. The financial and asset management of village includes planning, implementation, administration, reporting and accountability. Meanwhile, the financial and asset accountability report includes: village government budget (APBDES), village fund accountability reports, village fund allocation accountability reports, and fund aid accountability reports. Further, the village financial management includes two things. The first is planning of APBDES: income and expenditure. Then the second is collecting revenues from various sources: village own-source income, community self-help, government support, etc.

Table 1

Primary Areas Financed by Village Finance

\begin{tabular}{|c|c|c|}
\hline No & Areas & Elements \\
\hline 1 & Governance & $\begin{array}{l}\text { village official salary; } \\
\text { equipment and } \\
\text { operational office; village } \\
\text { office maintenance; } \\
\text { electricity taxes; official } \\
\text { travel; guest banquet, } \\
\text { meetings; BPD trials/ } \\
\text { hearings/meetings; BPD } \\
\text { salary (if any); media } \\
\text { subscription; etc. Other } \\
\text { considerations: cost } \\
\text { for human resource } \\
\text { improvement, village } \\
\text { revenues; village } \\
\text { publications; information } \\
\text { board, etc. }\end{array}$ \\
\hline 2 & Development & $\begin{array}{l}\text { Village physical } \\
\text { infrastructure; } \\
\text { maintanance; productive } \\
\text { economy, agriculture, etc. }\end{array}$ \\
\hline 3 & Incredibility & $\begin{array}{l}\text { LKMD activities, PKK } \\
\text { empowerment, youth } \\
\text { coaching, farmer } \\
\text { groups, religious-related } \\
\text { activities, handling } \\
\text { juvenile delinquency, etc. }\end{array}$ \\
\hline
\end{tabular}

Source: Amerieska, Siti 2015

Based on the Regulation of Ministry of Home Affairs No. 113 Year 2014, the cash income by village government may be in the forms of village revenues from the village own-source income, transfer income, other income, or others sourced from financing receipts. Besides, the cash expenditure by the village government can be in the forms of expenditure in village governance enforcement, village development implementation, community coaching, and other unexpected expenditure.

The accounting information system for cash income and expenditure provides useful information for the decision making by the management. The financial statement of village involves five activities (Yuliansyah \& Rusmianto, 2015). The cycle of village financial administration begins with the enactment of village regulations on the Village 
Government Budget (APBDesa). Based on APBDesa, the village government performs financial transactions in the form of cash income as a source of village income and also does cash expenditure for running village operational and programs. Based on legal financial transaction receipts, especially the payment letter, the village treasurer records in cash books (general ledger, tax auxiliary book, and bank book). The village treasurer posts the cash books to each account in the ledger. Afterward, the treasurer prepares a trial balance which summarizes the balance of each account in the ledger. The treasurer then calculates and adjusts the accounts related to current assets as the preparation stage of organizing the village-own assets reports. Last, the general village treasurer prepares the financial statements.

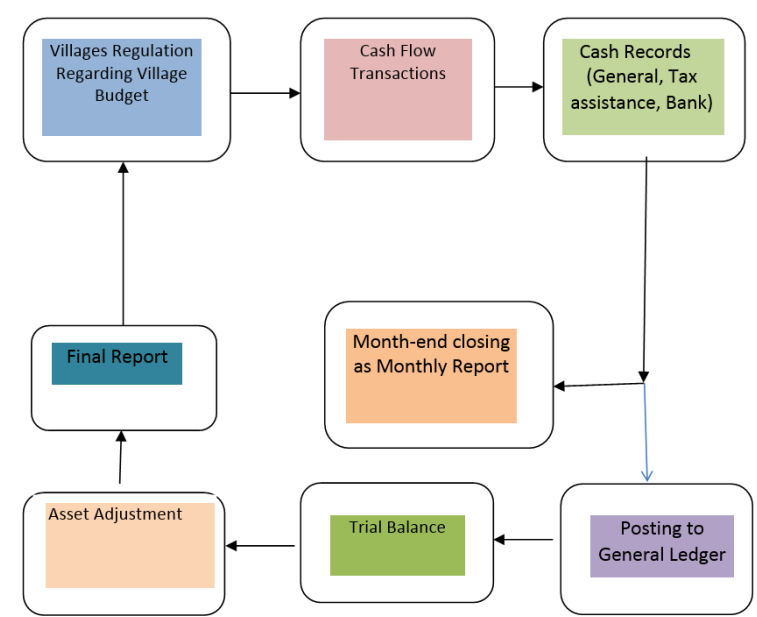

Figure 1. Village Funds Management Cycle

Source: Regulation of the Ministry of Home Affairs No 113 of 2014

Information Systems (IS) effectiveness is an effort made by organization to utilize the ability and the potential of IS owned to achieve the objectives (Simatupang and Akib 2007). A village administration can be called as having effective IS if by using that IS, the objectives of the organization are achieved. The same can be said for the utilization of effective IS will promote the accountability of village funds and the performance of good governance providence. The involvement of top management in the implementation of IS is an important matter. Top or leader management have a strong impact on all aspects in an organization led including the use of IS as a means in finishing the task.

A study conducted by Gupta et al. (2007) gave empirical evidence that the effectiveness of information system on public sector of an organization is highly determined by some factors such as top management, Information System (IS) management, organization's culture, users' satisfaction, and IS users. This study reviewed factors which influence the effectiveness of IS in village government. This study was aimed to find out factors which influence the effectiveness of IS on village funds system. Those factors are then expected to improve the accountability of village funds in order to create good governance.

\section{Research Method}

Population is generalization area that consists of objects/subjects which possess certain qualities and characteristics set by the researcher to be studied and then to be drawn a conclusion (Sugiyono, 2011, 73). The population of this study was all villages in Semarang Regency. Meanwhile, sample was part of population that own the characteristics (Sugiyono, 2011, 70). The sampling technique used is Quota Sampling by determining sample from population which has certain characteristics and desired number. Semarang Regency consists of 19 sub-districts which include 208 rural villages and 27 urban villages. The following is the list of villages in Semarang Regency (Table 2).

\section{Table 2}

A List of Rural/Urban Villages in Semarang Regency

\begin{tabular}{llcc}
\hline No & Sub-district & $\begin{array}{c}\text { Number } \\
\text { of Rural } \\
\text { Villages }\end{array}$ & $\begin{array}{c}\text { Number } \\
\text { of Urban } \\
\text { Villages }\end{array}$ \\
\hline 1 & Ungaran Barat & 6 & 5 \\
2 & Ungaran Timur & 5 & 5 \\
3 & Bergas & 9 & 4 \\
4 & Pringapus & 8 & 1 \\
5 & Bawen & 10 & 2 \\
6 & Bringin & 16 & - \\
7 & Tuntang & 16 & - \\
8 & Pabelan & 17 & - \\
9 & Bancak & 9 & - \\
10 & Suruh & 17 & - \\
11 & Susukan & 13 & - \\
12 & Kaliwungu & 11 & - \\
13 & Tengaran & 15 & \\
14 & Getasan & 13 & - \\
15 & Banyubiru & 10 & \\
16 & Sumowono & 16 & \\
17 & Ambarawa & 7 & \\
18 & Jambu & 11 & \\
19 & Bandungan & 9 & \\
\hline
\end{tabular}


Ungaran Barat (West Ungaran) and Ungaran Timur (East Ungaran) subdistricts were chosen as sample because they were advanced and densely populated areas. In accordance with the review of this study regarding the implementation of village regulations, thus 6 villages in Unggaran Barat Sub-district and 5 villages in Unggaran Timur Sub-district were taken as samples.

The data in this study were obtained using survey and contact person methods with questionnaires as the instrument. This study used primary and secondary data. Primary data were obtained by distributing questionnaire directly to find out the operational activity of Village funds. This questionnaire used to obtain the data regarding the receipt level, the distribution, and treasurer accountability report of village funds. That primary data were obtained in depth through observation, documentation, and questionnaire. The researchers observed (field survey) the research objects by conducting direct interview to parties involved with the management of Village Funds. The questionnaire was addressed to the managers and the beneficiary of the concerned Village Funds. 100 envelopes of questionnaires were distributed proportionally to the selected Villages. The questionnaire was used to do participative interview to the informant of the chosen village funds management.

All variables of this study were adopted from instruments made by Gupta et al (2007). The dependent variable of this study was the effectiveness of IS operated as an effort to utilize IS ability and potential to achieve the objectives of the organization. Top management referred to as management of understanding the information system, the interest, the support, and the knowledge of IS in the organization. Users' satisfaction is a respond and feedback given by the users after using IS. Users' attitude toward IS is a subjective criterion regarding how satisfied they are on the operating system. Organization's culture is a value system conducted by the members of organization which influences the strategy and the performance of organization.

Multiple regression was a statistical method used to test the hypothesizes of this study. The program used to test the hypothesizes was SPSS program 13,5. $Y=a+$ $b 1 X 1+b 2 X 2+b 3 X 3+b 4 X 4,+b 5 X 5+$ e. $Y 1=$ the Effectiveness of Information System, $X 1=$ Top Management, $X 2=$ Information System Management, X3 = Users' Satisfaction, X4= Organization Culture, $\mathrm{X} 5=$ Information System

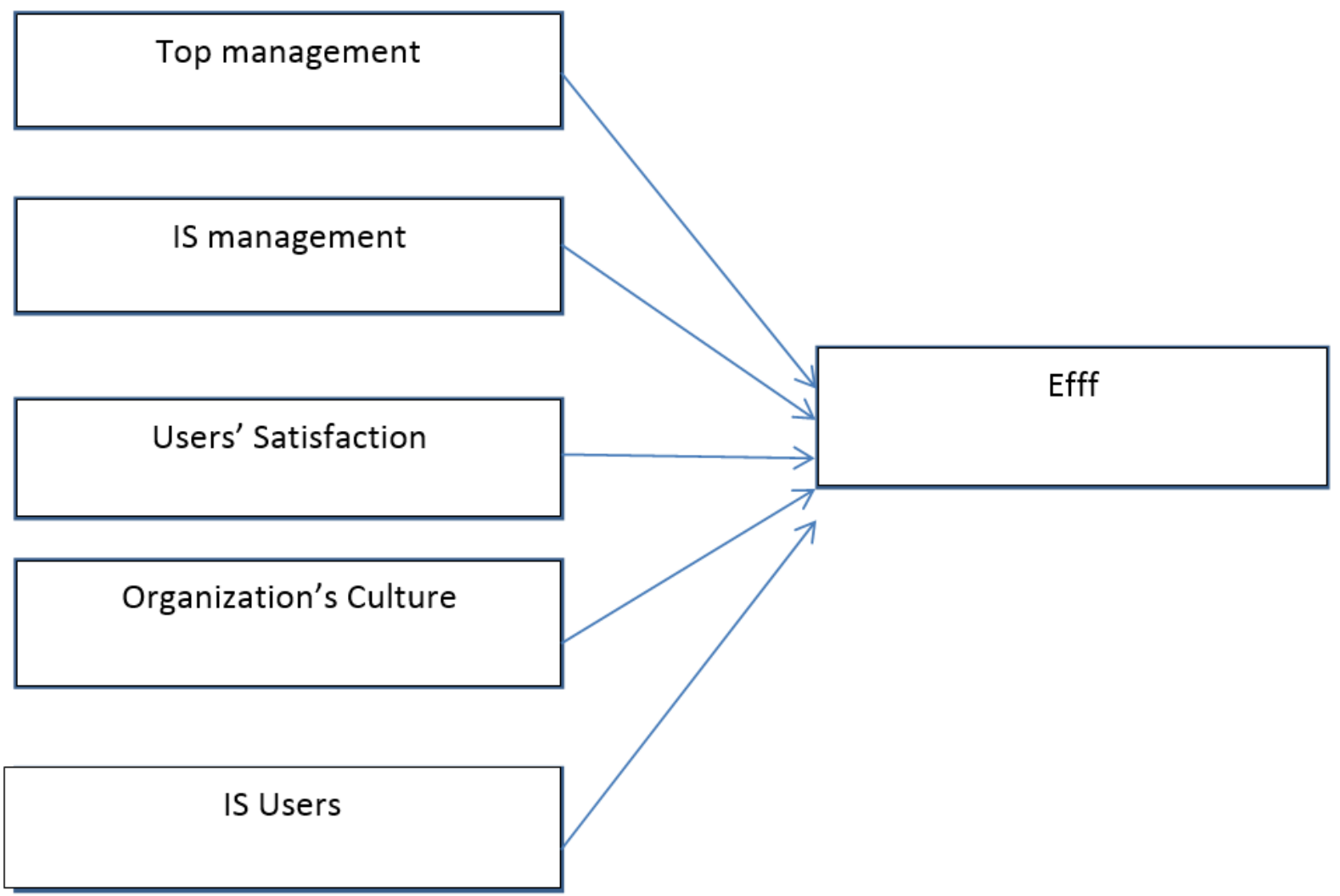


Users, $a=$ constants, $b=$ regression coefficient, $€=$ error. The referred top management was the village chief, while the referred information system management was village treasurer. The model of this study was visualized in figure 3 .

Gupta et al (2007) stated that top management, IS management, users' satisfaction in government organization is expected to have a better and strong impact on IS planning and implementation in the future. Hypothesises of this study are:

$\mathrm{H} 1$ : Top management has positive correlation with IS effectiveness.

$\mathrm{H} 2$ : IS management has positive correlation with IS effectiveness.

H3: Users' satisfaction has positive correlation with IS effectiveness.

H4: Organization's culture has positive correlation with the effectiveness of IS management.

H5: Information system users have positive correlation with the effectiveness of IS management.

A study conducted by Handayani, Rini (2010) supported three out of five hypothesizes proposed. They are: top management, IS management, and IS users have positive correlation with IS effectiveness. Meanwhile, users' satisfaction and organization's culture do not have positive correlation with IS effectiveness. The differences between this study with the study conducted by Handayani, Rini (2010) is on the sample's characteristic which is Semarang Regency.

\section{Discussion}

100 questionnaires were sent to ten villages in Ungaran Barat and Unggaran Timur. All respondents answered $100 \%$ and gave the questionnaires back to be processed. Respondents' characteristics such as their gender, age, and education background were presented as follows.

Table 3

Respondents' Characteristics

\begin{tabular}{lll}
\hline $\begin{array}{l}\text { Characteristics } \\
\text { Gender }\end{array}$ & Frequency & $\%$ \\
\hline $\begin{array}{l}\text { Female } \\
\text { Male }\end{array}$ & 18 & 36,0 \\
Age & 32 & 64,0 \\
$<21$ years old & 1 & 2,0 \\
$21-30$ years old & 21 & 42,0 \\
$31-40$ years old & 13 & 28,0
\end{tabular}

\begin{tabular}{lll} 
41-50 years old & 10 & 20,0 \\
$\begin{array}{l}\text { 51-60 years old } \\
\text { Education }\end{array}$ & 4 & 8,0 \\
$\begin{array}{l}\text { Elementary School } \\
\text { Junior High School }\end{array}$ & 1 & 2,0 \\
$\begin{array}{l}\text { Senior High School or } \\
\text { Equivalent }\end{array}$ & 25 & 2,0 \\
D1 & 1 & 50,0 \\
D3 & 10 & 2,0 \\
S1 & 12 & 20,0 \\
\hline
\end{tabular}

Based on Table 3, it is known that most of the respondents were male; they were 21-30 years old; they were high schools graduates. The following were the responses of the respondents regarding top management, IS management, users' satisfaction, organization's culture, and IS users. Those responses were presented by showing the mean, minimum score, maximum score, and standard deviation. The variable is considered to get a low response if the mean is in the interval between 1 to 2,3; the variable is considered to get an adequate response if the mean is in the interval between $>2,3$ to. 3,7 ; and the variable is considered to have a high response if the mean is in the interval between $>3,7$ to 5 . Table 4 below is a statistical description of the variables of the effectiveness of information system in details.

\section{Table 4 \\ The Scores of Respondents' Answer Based on the Research Variables}

\begin{tabular}{|c|c|c|c|c|c|}
\hline & $\mathrm{N}$ & Min & Max & Mean & $\begin{array}{l}\text { Standard } \\
\text { Deviation }\end{array}$ \\
\hline $\begin{array}{l}\text { Top Man- } \\
\text { agement }\end{array}$ & 50 & 2 & 5 & 3.81 & 0.517 \\
\hline $\begin{array}{l}\text { IS Manage- } \\
\text { ment }\end{array}$ & 50 & 3 & 5 & 3.77 & 0.459 \\
\hline $\begin{array}{l}\text { Users' Sat- } \\
\text { isfaction }\end{array}$ & 50 & 3 & 5 & 3.91 & 0.397 \\
\hline $\begin{array}{l}\text { Organiza- } \\
\text { tion's Cul- } \\
\text { ture }\end{array}$ & 50 & 2 & 4 & 3.06 & 0.413 \\
\hline IS Users & 50 & 1 & 4 & 3.28 & 0.815 \\
\hline $\begin{array}{l}\text { The Effec- } \\
\text { tiveness of } \\
\text { Information } \\
\text { System }\end{array}$ & 50 & 3 & 5 & 4.00 & 0.394 \\
\hline
\end{tabular}

Based on Table 4, it can be seen that the highest average score of 4.00 was gained from the variable effectiveness of information system, which shows that among these six variables studied, the effectiveness of information system is the most perceived variable by the respondents. Next, the 
second highest average score is 3.91 which was reached through user's satisfaction variable, then followed by top management with average score of 3,81 while information system management placed the fourth rank with the average score of 3.77. Meanwhile, the variables considered fair are organization culture and information system user with the average score of 3.06 and 3.28 .

In addition, instrument test aimed to discover the quality of the measuring instruments, including validity test and reliability test. Thus, the instrument test was conducted toward the research questionnaire. The questionnaire was distributed to 50 respondents as the research sample. Then, the validity and reliability were tested using computer program assistance SPSS version 15.

On the other hand, validity test was used to find out the eligibility of the question items in defining a variable (Ghozali, 2007). Hence, the question item is regarded valid if the $r$ calculation value (item-total correlation) is bigger than $r$ table value. Nevertheless, the $r$ table value is obtained from the $r$ product moment Pearson value of one-tailed test with $d f=n-2$. Hence, $d f=50-2=48$, thus the $r$ table $=0.23523$. The result of validity test per question item is presented in Table 5 below.

\section{Table 5}

Result of Validity Test

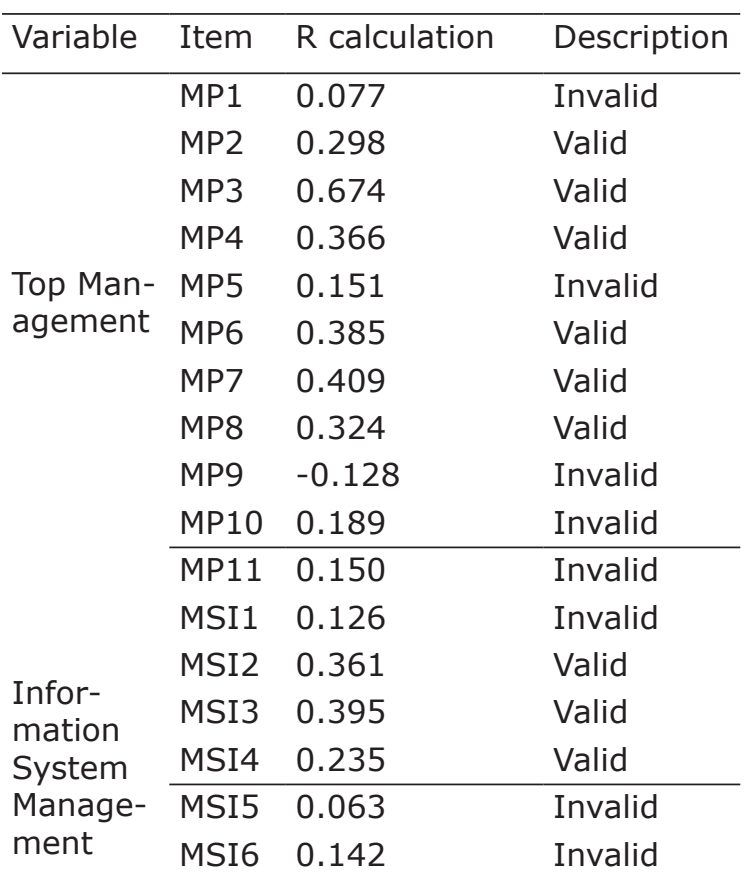

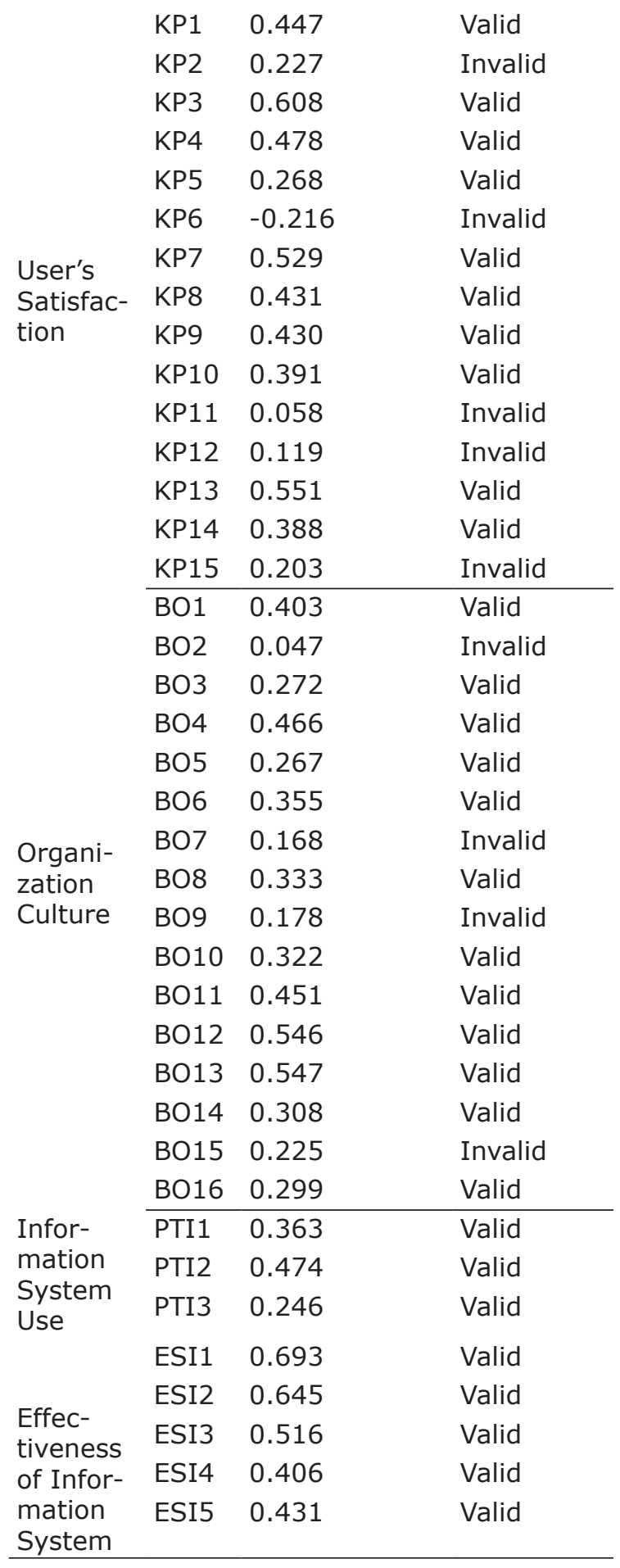

Source: Analyzed Data

Based on Table 5, there are some items whose value is less than $r$ table, therefore those items were eliminated. In the next analysis, the researcher used items that had been validated. In addition, reliability test was objected to measure stability and consistency of respondents in answering question items in the dimension of variables and compiled in a questionnaire (Ghozali, 2009). Reliability test, furthermore, was tested to the instruments 
that had been validated in validity test, while the invalid/drop statements were not done any reliability test. Reliability test was conducted by the assistance of SPSS Program version 15 with Alpha Cronbach test. If, the a value of the variable tested is bigger than $r$ table $(0,2353)$, then the variable is considered as reliable (Santoso, 2000). The result of reliability test of all variables can be seen in Table 6.

\section{Table 6}

Result of Reliability Test

\begin{tabular}{|c|c|c|c|}
\hline Variable & $\begin{array}{l}\text { Question } \\
\text { Items }\end{array}$ & $\begin{array}{l}\text { Cronbach's } \\
\text { Alpha }\end{array}$ & Description \\
\hline $\begin{array}{l}\text { Top Man- } \\
\text { agement }\end{array}$ & 6 & 0,772 & Reliable \\
\hline $\begin{array}{l}\text { IS Man- } \\
\text { agement }\end{array}$ & 3 & 0,529 & Reliable \\
\hline $\begin{array}{l}\text { User's } \\
\text { Satisfac- } \\
\text { tion }\end{array}$ & 10 & 0,798 & Reliable \\
\hline $\begin{array}{l}\text { Organi- } \\
\text { zation } \\
\text { Culture }\end{array}$ & 12 & 0,778 & Reliable \\
\hline IS User & 3 & 0,529 & Reliable \\
\hline $\begin{array}{l}\text { Effective- } \\
\text { ness of In- } \\
\text { formation } \\
\text { System }\end{array}$ & 5 & 0,763 & Reliable \\
\hline
\end{tabular}

Source: Processed Primary Data, 2016

From Table 6, we know that Cronbach's alpha (a) value of the six variables studied is above 0.2353 . Therefore, it can be concluded that the variables employed in this research fulfill the reliability level required. Normality test used in this research was One Sample Kolmogorov-Smirnov Test completed with observation through histogram graphic. If the residual has Asymp. Sig (2-tailed) under the significance level of 0,05 (probability $<0,05$ ) in One-Sample Kolmogorov-Smirnov Test, , it is defined that those variables are abnormal and vice versa.

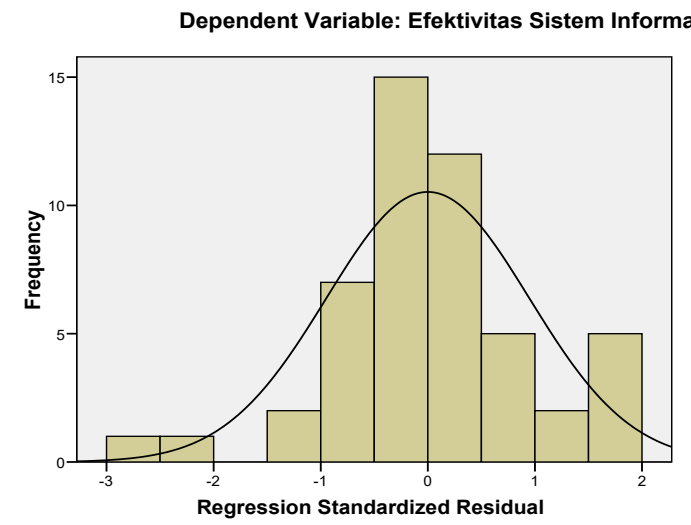

Normal P-P Plot of Regression Standardized Residual

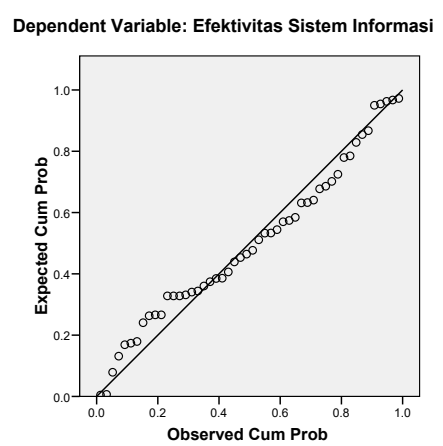

Figure 5. The Graph of Normality Test

From the histogram graphic, the bars are located right in the middle, so it can be said that the data is normally distributed, whereas, in the next pictures, the spots are spread around the diagonal line, hence, we can say that it is normally distributed. In addition, thereto, the result of normality test is more valid with Kolmogorov Smirnov test, as it is presented in Table 7.

\section{Table 7 Normality Test}

\begin{tabular}{|c|c|c|}
\hline \multicolumn{3}{|c|}{ One-Sample Kolmogorov-Smirnov Test } \\
\hline & & $\begin{array}{l}\text { Unstandardiz } \\
\text { ed Residual }\end{array}$ \\
\hline \multicolumn{2}{|l|}{$\mathrm{N}$} & 50 \\
\hline \multirow[t]{2}{*}{ Normal Parameters a,b } & Mean & .0000000 \\
\hline & Std. Deviation & 1.19625997 \\
\hline Most Extreme & Absolute & .099 \\
\hline \multirow[t]{2}{*}{ Differences } & Positive & .072 \\
\hline & Negative & -.099 \\
\hline Kolmogorov-Smirnov Z & & .702 \\
\hline Asymp. Sig. (2-tailed) & & .709 \\
\hline
\end{tabular}

From the statistic score, Asymp values were obtained above 0.05 which was 0.709 . The sig value is bigger than $5 \%$ showing that this research strengthens the result obtained through graphic so it is proven that the data was normally distributed. Moreover, multicollinearity test was objected to discover any correlation among independent variables in regression model. Correlation among independent variables must not be found in a good regression model. Hence, in order to check any multicollinearity in regression, we can use these following things: (1) tolerance value and (2) variance inflation factor (VIF) value. On the other hand, a regression model which is free from multicollinearity has tolerance value above 0.1 or VIF under 10 
(Ghozali, 2007). On contrast, multicollinearity can emerge if tolerance value under 0.1 or VIF above 10 . The result of multicollinearity test can be studied in Table 8 .

\section{Table 8}

The Results of Multicollinearity Test

Coefficientsa

\begin{tabular}{|ll|r|c|}
\hline \multirow{2}{*}{ Model } & \multicolumn{2}{|c|}{ Collinearity Statistics } \\
\cline { 3 - 4 } & & Tolerance & \multicolumn{1}{c|}{ VIF } \\
\hline & Manajemen Puncak & .722 & 1.386 \\
& Manajemen SI & .659 & 1.517 \\
& Kepuasan Pengguna & .677 & 1.476 \\
& Budaya Organisasi & .707 & 1.414 \\
& Pengguna SI & .895 & 1.117 \\
\hline
\end{tabular}

a. Dependent Variable: Efektivitas Sistem Informasi

Note:

Manajemen Puncak= Top Management

Manajemen SI= SI Management

Kepuasan Pengguna = User's Satisfaction

Budaya Organisasi $=$ Organization Culture

Pengguna SI= SI UserDependent Variable= Effectiveness of Information System

Based on Table 8, it can be identified that the tolerance value is ranged from 0.659 until 0.895 , and the VIF value is ranged from 1,117 to 1,517 . The smallest tolerance values is bigger than 0.1 and the biggest VIF value is 1.517 which is smaller than 10 . Hence, it can be assumed that regression model does not contain multicollinearity, so the analysis could still be continued.

Besides, autocorrelation test was objected to reveal whether the regression model is correlated between the intruder's mistake in t period with intruder's mistake in the previous period ( $\mathrm{t}-1)$. If there is any correlation, then it is called autocorrelation problem. There are some ways to detect autocorrelation indications, however, in this research we used Run test. According to Ghozali (2009), the model is independent from autocorrelation problems if the Sig. value is bigger than 0,05.

Table 9

Autocorrelation Test

Runs Test

\begin{tabular}{|l|r|}
\hline & Unstandardized Residual \\
\hline Test Valuea & 0 \\
Cases < Test Value & 25 \\
Cases >= Test Value & 25 \\
Total Cases & 50 \\
Number of Runs & 27 \\
Z & .286 \\
Asymp. Sig. (2-tailed) & .775 \\
\hline
\end{tabular}

a. Median
As seen in Table 9, we used Run Test to find out the value of autocorrelation and it resulted to 0.775 , bigger than 0.05 , hence we can conclude that the model is free from autocorrelation problem.

On the other hand, heteroscedasticity test was aimed to test any different variance of one residual in regression model from one observation to another observation. If the variance of residual from one observation to another observation is still the same, it is called as homoscedasticity, yet, if it is different, it is called heteroscedasticity (Ghozali, 2009). In order to detect any heteroscedasticity, we used park test. Park test is a regression of independent variable toward natural logarithm and residual square main model. If independent variable is statistically significant, then it is identified as heteroscedasticity. As a matter of fact, the participant must take heteroscedasticity test in form of graphic before taking park test. The result of heteroscedasticity test can be read in Figure 6.

Scatterplot

Dependent Variable: Efektivitas Sistem Informasi

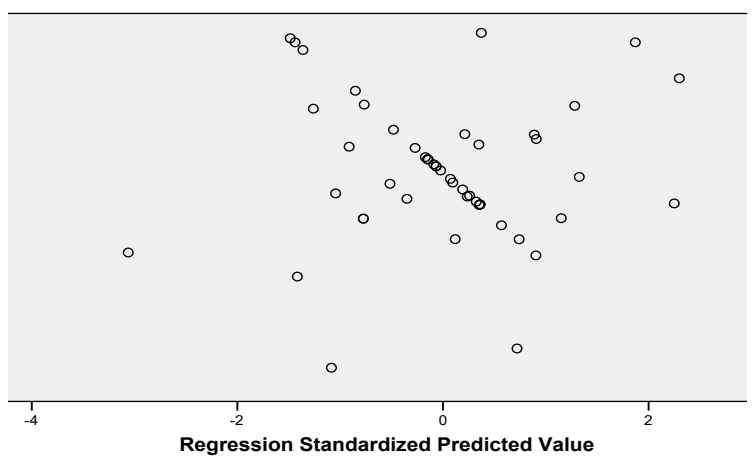

Figure 6

Graph of Heteroscedasticity Test

The scatterplot graphic showing spots distributed does not make a line pattern and wave pattern or common patterns, so it can be said that it is free from heteroscedasticity problem. It is proven by statistic test as it is shown in Table 10.

Table 10

Heteroscedasticity Test Using Park Test Method

\begin{tabular}{|c|c|c|c|c|c|c|}
\hline \multicolumn{7}{|c|}{ Coefficientsa } \\
\hline \multirow[b]{2}{*}{ Model } & & \multicolumn{2}{|c|}{$\begin{array}{c}\text { Unstandardized } \\
\text { Coefficients }\end{array}$} & \multirow{2}{*}{$\begin{array}{c}\text { Standardized } \\
\text { Coefficients }\end{array}$} & \multirow[b]{2}{*}{$t$} & \multirow[b]{2}{*}{ Sig. } \\
\hline & & $\mathrm{B}$ & Std. Error & & & \\
\hline 1 & $\begin{array}{l}\text { (Constant) } \\
\text { (a) }\end{array}$ & .902 & 3.557 & & .253 & .801 \\
\hline & Manajemen Puncak & -.203 & .116 & -293 & -1.746 & .088 \\
\hline & Manajemen SI & -.060 & 274 & -.039 & -.221 & .826 \\
\hline & Kepuasan Pengguna & 112 & .094 & 208 & 1.197 & .238 \\
\hline & Budaya Organisasi & .027 & .073 & .063 & .371 & .713 \\
\hline & Pengguna SI & - -196 & .132 & -.224 & -1.485 & .145 \\
\hline
\end{tabular}


Table 10 of park test result shows that $t$ calculation value is not statistically significant, which means, the sig value reached is not smaller than 0.05. Thus, we can conclude that the model is free from heteroscedasticity problem.

Meanwhile, double liner regression was objected to discover the effect of top management, information system management, user satisfaction, organization culture and information system user toward the effectiveness of information system. Multiple linear regression test includes $\mathrm{F}$ test, t test, and Determination Coefficient test.

Based on table 11 , the regression coefficient is obtained for each free variable: top management, information systems management, users satisfaction, organizational culture and user of information systems. The result of multiple linear regression statistical tests shows a regression equation as follows: $\mathrm{ESI}=0,193 \mathrm{MP}-0,052 \mathrm{MSI}+0,644 \mathrm{KP}+$ 0,226BO - 0,087PSI.

The equation of regression analysis result will be explained in this section. Firstly, the regression coefficient of top management variable (X1) is 0,193 , which means if the free variable is considered fixed, the increasing of top management variable will be 1 unit followed by the increasing of information system effectiveness which is 0,193 point. Secondly, the regression coefficient of information systems management variable (X2) is 0,052 , meaning if the free variable is considered fixed, the increasing of this variable is 1 unit followed by the decreasing of the information system for 0,052 points. Thirdly, the regression coefficient of users satisfaction variable (X3) is 0,644 , which indicates if the other free variables are considerably fixed, the increasing of users satisfaction variable in 1 unit is followed by the increase of information system effectiveness in 0,644 points. Fourthly, the regression coefficient of organizational culture variable $(X 4)$ is 0,226 , in which if the other free variables are presumably fixed as well, the increasing of organizational culture variable in 1 unit is followed by the increase of information system effectiveness in 0,226 points. Finally, the regression coefficient of users of systems information variable (X5) is 0,087 , indicating if the other free variables are considerably fixed, the increasing of users of systems information variable in 1 unit is followed by the decreasing of information system effectiveness in 0,087 points.

$F$ test aims to see the simultaneous effect of top management, information system management, users satisfaction, organizational culture, and information system users to the information system effectiveness. Based on table 11, ANOVA and $F$ tests obtain the calculation value of $F$ in 15,045 with significance level in 0,000 . The probability significance is much smaller than 0,05 so that the regression model could be used to predict the effectiveness of information system.

The coefficient of determination test aims to see how the top management, information system management, users satisfaction, organizational culture, and

Table 11

The result of multiple linear regression tests

\begin{tabular}{|c|c|c|c|c|c|c|}
\hline \multirow{2}{*}{$\begin{array}{l}\text { Model } \\
1\end{array}$} & \multicolumn{2}{|c|}{ Variable } & \multicolumn{2}{|c|}{$\begin{array}{l}\text { Standardized } \\
\text { Coefficients } \\
\text { Beta }\end{array}$} & \multirow{2}{*}{$\begin{array}{l}\mathrm{t} \\
1,400\end{array}$} & \multirow{2}{*}{$\begin{array}{l}\text { Sig. } \\
0,168\end{array}$} \\
\hline & \multicolumn{2}{|c|}{ (Constant) } & & & & \\
\hline & \multicolumn{2}{|c|}{ Top Management } & \multicolumn{2}{|l|}{0,193} & 1,786 & 0,081 \\
\hline & \multicolumn{2}{|c|}{$\begin{array}{l}\text { Information System } \\
\text { Management }\end{array}$} & \multicolumn{2}{|l|}{$-0,052$} & $-0,459$ & 0,649 \\
\hline & \multicolumn{2}{|c|}{ Users satisfaction } & \multicolumn{2}{|l|}{0,644} & 5,786 & 0,000 \\
\hline & \multicolumn{2}{|c|}{ Organizational Culture } & \multicolumn{2}{|l|}{0,226} & 2,073 & 0,044 \\
\hline & \multicolumn{2}{|c|}{ System Information Users } & \multicolumn{2}{|l|}{$-0,087$} & $-0,896$ & 0,375 \\
\hline $\mathrm{F}$ & & $: 15,045$ & Sig: & 0,000 & & \\
\hline $\mathrm{R}$ & & : 0,794 & & & & \\
\hline \multicolumn{2}{|c|}{ R square } & : 0,631 & & & & \\
\hline \multicolumn{2}{|c|}{ Adj. R square } & : 0,589 & & & & \\
\hline
\end{tabular}


information system users explain the information systems effectiveness. Based on table 11 , it shows that the Adjusted R Squared value is 0,589 , which indicates that the variation of information systems effectiveness could be explained by the five free variables in $58,9 \%$, while the remaining value $(100 \%$ $58,9 \%=41,1 \%$ ) is described by other factors outside the research.

The result of the hypothesis test is obtained based on the result of t-test in table 11. The first hypothesis says that the top management affects the information system effectiveness. The result of hypothesis test obtains the sig. value 0,081 bigger than 0,05 , and t calculation is 1,786 smaller than $t$ value in the table $( \pm 2,0154)$. The $t$ value is positive but not significant, which means that $\mathrm{Ho}$ is accepted, and $\mathrm{Ha}$ is rejected, in which there is a positive and not significant effect of top management to the information system effectiveness. So, the first hypothesis saying that top management positively affects the information system effectiveness rejected.

The second hypothesis says that information system management affects the effectiveness of information system. The result of statistical test obtains sig. value 0,649 bigger than 0,05 and the $t$ value is $-0,459$ smaller than the $t$ value in the table $( \pm 2,0154)$. It can be seen that the $t$ value is negative, but it is not significant, which means that $\mathrm{Ho}$ is accepted, and $\mathrm{Ha}$ is rejected, there is a negative yet insignificant influence of information system management variables to the information system effectiveness. In other words, the second hypothesis saying that information system management positively affects the information system effectiveness is rejected.

The third hypothesis says that the users' satisfaction affects the information system effectiveness. The result of statistical test obtains sig. value 0, 000 smaller than 0,05 and the $t$ value is 5,786 bigger than the $t$ value in the table $( \pm 2,0154)$. It can be seen that the $t$ value is positive and significant, which means that $\mathrm{Ho}$ is rejected, and $\mathrm{Ha}$ is accepted, and there is a positive and significant influence of users' satisfaction variables to the information system effectiveness. Therefore, the third hypothesis, saying that user satisfaction positively affects the information system effectiveness, is accepted.

The fourth hypothesis says that the organizational culture affects the information system effectiveness. The result of statistical test obtains sig. value 0,044 smaller than 0,05 and the $t$ value is 2,073 bigger than the $t$ value in the table $( \pm 2,0154)$. As it is shown that the $t$ value is positive and significant, which means that $\mathrm{Ho}$ is rejected, and $\mathrm{Ha}$ is accepted, there is a positive and significant influence of organizational culture variables to the information system effectiveness. So, the fourth hypothesis, saying that organizational culture positively affects the information system effectiveness, is accepted.

The fifth hypothesis says that the information system users affect the information system effectiveness. The result of statistical test obtains sig. value 0,375 bigger than 0,05 and the $t$ value is $-0,896$ smaller than the $t$ value in the table $( \pm 2,0154)$. It shows that $\mathrm{t}$ value is negative but insignificant, which means that Ho is accepted, and $\mathrm{Ha}$ is rejected, there is a negative and insignificant influence of information system user variables to the information system effectiveness. So, the fifth hypothesis, saying that information system users positively affect the information system effectiveness, is rejected.

Based on the discussion above, it can be concluded that the three hypothesizes stating that top management, information system management, information system users understandably affect the effectiveness of information systems are rejected. In other words, the three hypotheses do not influence the effectiveness of village's financial information systems. Based on the data analysis, users satisfaction and organizational culture positively influence the effectiveness of village's financial information systems. This result correspondingly agrees with Gupta's research (2007), which implies the higher users satisfaction, the higher effectiveness of village's financial information systems. The same conclusion applies to the organizational culture as well, in which the more conducive the organizational culture of village governance, the higher effectiveness of village's financial information systems. Thus, two factors that can be used as a consideration to determine the effectiveness of village's financial information systems are user satisfaction and organizational culture of the village governance.

\section{Conclusion}

This research attempts to test the effect of top management, information system management, user satisfaction, 
organizational culture and information system users on the effectiveness of village financial information system. The primary data is collected from the samples of 10 villages in Semarang that receive funding. The result of multiple regression has successfully proven that the users' satisfaction and organizational culture positively influence the effectiveness of information system. Differently, top management, information system management and information system users do not have effects on the effectiveness of information system.

Due to the limited time, it is impossible for the researchers to test factors outside the measured variables. The result of this study is expected to be useful to provide more references for the rural governance in Semarang and beyond.

\section{References}

Amerieska, Siti. (2015). Pengembangan Model Akuntabilitas Pengelolaan Keuangan dan Aset Desa Berbasis Shariate Enterprise Theory. Syariah Paper Accounting FEB UMS.

Bastian, Indra. (2006). Akuntansi Sektor Publik: Suatu Pengantar, Jakarta: Penerbit Erlangga.

Ghozali, Imam. (2007). Aplikasi Analisis Multivariate dengan Program SPSS. Semarang: Badan Penerbit Universitas Diponegoro

Gupta M.P, Kanungo S, Kumar R and Sahu G.P. (2007). A Study of Information Technology Effectiveness in Select Government Organization in India. Journal for Decision
Makers, Vol 32 No. 2

Handayani, Rini. (2010). Analisis Faktor faktor yang Menentukan Efektifitas Sistem Informasi pada Organisasi Sektor Publik. Jurnal Akuntansi dan Keuangan, Vol. 12, No. 1 Mei, Hal: 26-40

Maggasingang, Djainuddin. (2015). Pengembangan Model Tata-Kelola Keuangan dalam Mengoptimalkan Anggaran Belanja Kota Makassar. MIMBAR, Vol. 31, No. 2 (Desember, 2015): 429-438

Santoso, Singgih. (2000). Buku Latihan SPSS: Statistik Parametrik, Jakarta: Elex Media Komputindo

Setyoko, I Paulus. (2011). Akuntabilitas Administrasi Keuangan Program Alokasi Dana Desa (ADD). Jurnal Ilmu Administrasi Negara, Vol 11, No. 1, Januari, Hal: 14-24

Simatupang, Patar dan Akib, Haedar .(2007). Potret Efektifitas Organisasi Publik : Review Hasil Penelitian. Manajemen Usahawan Indonesia, No. 01. Th XXXVI

Sugiyono. (2011). Statistika untuk Penelitian. Edisi pertama. Bandung: Alfabeta

Yuliansyah \& Rusmianto. (2015). Akuntansi Desa. Jakarta: Penerbit Salemba Empat

Yusnita, Y Nina (2010). Pengaruh Penerapan Prinsip-prinsip akuntansi terhadap kualitas laporan keuangan sektor publik dengan akuntabilitas publik dan transparansi sebagai variabel moderating (Studi pada Satuan Kerja Perangkat Daerah Kota Palu). Jurnal Akuntansi \&Auditing, Vo. 7, No 1, November, Hal: 19-30.

Zulfida I, Fauzi A, Rustiadi E, Syaukat Y. (2015). Kinerja Program Nasional Pemberdayaan Masyarakat Mandiri Perdesaan di Kabupaten Bandung. MIMBAR, Vol. 31, No2, (Desember, 2015): 307-318 